\title{
KAIDAH-KAIDAH PENATAAN RUANG DALAM RANGKA PENGELOLAAN LINGKUNGAN (Kajian Yuridis)
}

\begin{abstract}
Agus Widodo *
ABSTRACT

Spatial planning is aimed at realizing harmony between the natural environment and the artificial environment, the integrated use of natural resources and artificial resources. Spatial planning is also intended to protect the function of space and environmental preservation. According to Law No. 26 of 2007 concerning Spatial Planning, space is based on all interests in an integrated, efficient and effective, harmonious, harmonious and balanced manner. The problem formulation in this study is How are the rules of spatial planning in the framework of environmental management? The first rule that must be held in spatial planning for development is that every change must be better than the previous day, namely a more prosperous, comfortable future without the fear of anxiety and fear of various phenomena, such as an unhealthy living environment because of unclear spatial planning. , natural disasters due to the blind use of natural resources and other actions without planning, without arrangement and others. The second principle in spatial planning is to do explicit territory in the long term or be thankful forever without change, because many spatial arrangements are so easy to change and only obey the wishes of the market or capital owners. Now we see a lot of productive agricultural land, productive plantation land, forests cleared to meet the demand of the market turned into industrial buildings, housing, and even green open space (RTH) and city parks turned into malls.
\end{abstract}

Keywords: Spatial Planning, Juridical Study Environment Management

\section{PENDAHULUAN}

Lingkungan bagi manusia merupakan salah satu unsur yang sangat penting dalam kehidupannya, karena lingkungan tidak saja sebagai tempat manusia beraktivitas, tetapi lingkungan juga sangat berperan dalam mendukung berbagai aktivitas manusia.Di lingkungan, semua kebutuhan hidup manusia telah tersedia sehingga ada upaya yang dilakukan oleh manusia untuk mengekploitasi lingkungannya demi hajad hidupnya. Merupakan hal yang sangat wajar bila

* Agus Widodo adalah Pengajar di Universitas 17 Agustus 1945 Semarang dapat dihubungi melalui email : anindahayu07@gmail.com interaksi manusia dengan lingkungannya akan berlangsung secara berkelanjutan dan terus- menerus. Dengan adanya interaksi ini, maka dapat dipastikan bahwa kondisi lingkungan juga akan dipengaruhi oleh perilaku manusia. Sikap dan perilaku manusia akan menentukan baik dan buruknya kondisi suatu lingkungan. Sebalik bagaimana manusia memperlaku kan lingkungan dampaknya akan ber pengaruh terhadap kualitas kehidupan manusia itu sendiri. Menurut Munadjat Danusaputro, lingkungan hidup adalah semua benda dan daya serta kondisi termasuk di dalamnya manusia dan tingkah perbuatannya, yang terdapat dalam ruang di mana manusia berada dan mempengaruhi 
kelangsungan hidup serta kesejahteraan manusia dan jasad-jasad hidup lainnya. ${ }^{1}$

Permasalah lingkungan hidup pada hakikatnya adalah permasalahan ekologi. Inti permasalahan lingkungan hidup adalah hubungan timbal balikantara makhluk hidup dengan lingkungannya. Apabila hubungan timbal balik antara makhluk hidup dengan lingkungan berjalan teratur dan seimbang serta merupakan satu kesatuan yang saling mempengaruhi, maka akan terbentuk suatu system ekologi yang lazim disebut ekosistem.

Secara yuridis pengertian ekosistem dirumuskan baik dalam UULH 1982, UULH 1997, maupun UULH 2009 diartikan sebagai tatanan unsur lingkungan hidup yang merupakan kesatuan utuh menyeluruh dan saling mempengaruhi dalam membentuk keseimbangan, stabilitas dan produktivitas lingkungan hidup.

Diantara komponen ekosistem, manusia adalah komponen yang paling dominan dan paling menentukan, karena manusia dengan akal budinya mempunyai kemampuan yang besar untuk mengubah atau mempengaruhi lingkungan hidup.

Manusia dalam menjaga ekosistem tidak bisa dipisahkan dengan pemanfaatan dengan lingkungan hidup itu sendiri.

Salah satu komponen penting dalam pemanfaatan lingkungan hidup agar tetap terjaga ekosistemnya dengan baik adalah penataan ruang dalam setiap rencana pembangunan.

Penataan ruang ditujuan untuk mewujudkan keharmonisan antara lingkungan alami dan lingkungan buatan, keterpaduan penggunaan sumber daya alam dan sumber daya buatan.Menata ruang dimaksudkan juga untuk melindungi fungsi ruang dan pelestarian lingkungan. Menurut Undang-Undang No. 26 Tahun 2007 tentang Penataan Ruang, ruang berazaskan

1 Munadjat Danusaputro, Hukum Lingkungan, Buku I Umum, Jakarta, Bina Cipta, 1985 halaman 67 bagi semua kepentingan secara terpadu, berdaya guna dan berhasil guna, selaras, serasi dan seimbang.

Perencanaan tata ruang dilakukan untuk menghasilkan rencana umum tata ruang dan rencana rinci tata ruang. Rencana umum tata ruang disusun berdasarkan pendekatan wilayah administrative dengan muatan substansi mencakup struktur ruang dan rencana pola ruang. Rencana rinci tata ruang disusun berdasarkan pendekatan nilai strategis kawasan dan atau kegiatan kawasan dengan muatan substansi yang dapat mencakup hingga penetapan blok dan sub blok peruntukan. Penyusunan rencana rinci tersebut dimaksudkan sebagai operasionalisasi rencana umum tata ruang dan sebagai dasar penetapan peraturan zonasi.

\section{PERUMUSAN MASALAH}

Bagaimanakah kaidah-kaidah penataan ruang dalam rangka pengelolaan lingkungan hidup?

\section{PEMBAHASAN}

\section{Kaidah Pembangunan Harus Lebih Baik Dari Sebelumnya}

Semula interaksi manusia dengan lingkungannya berjalan dalam kondisi yang berkeseimbangan. Manusia selalu berusaha menyesuaikan pola hidupnya dengan kondisi lingkungannya. Perilaku manusia terhadap lingkungan ditandai dengan sikap dan kearifan tindakan manusia terhadap alam yang terwujud dalam berbagai tradisi dan hukum adat yang dipatuhi oleh masyarakat. Namun pertambahan penduduk yang pesat berdampak pada bertambahnya kebutuhan manusia akan sumber daya yang diikuti dengan makin meningkat pula tekanan dan ekploitasi terhadap lingkungan. Hal ini boleh jadi tidak salah karena manusia dilahirkan dengan membawa naluri untuk mem 
pertahankan diri demi kelangsungan hidupnya. Mengekploitasi sumber daya yang disediakan lingkungan sebatas kebutuhan kelangsungan hidup merupakan perilaku yang wajar dan dapat diterima. Akan tetapi, tindakan manusia akan menjadi salah bila manusia memperlaku kan alam hanya berdasarkan keinginan dan kebutuhannya tanpa memperhatikan keseimbangan ekosistem.Pembangunan sebagai upaya perubahan suatu keadaan untuk menuju kepada suatu keadaan yang dianggap lebih baik dari keadaan sebelumnya. Upaya paling utama yang harus dilakukan adalah dimulai dalam diri setiap individu itu sendiri, baru kemudian meluas kepada lingkungan, karena setiap individu adalah penggerak dalam pelaksanaan pembangunan.

Perubahan adalah suatu kebutuhan dan bahkan mungkin dapat menjadi keharusan bagi setiap individu untuk menuju suatu keadaan yang dianggap lebih menjanjikan suatu kebahagiaan dan kenyamanan dalam hidup, maka upaya perubahan itu sendiri akan berdampak langsung terhadap lingkungan hidup. ${ }^{2}$

Keinginan manusia untuk hidup lebih baik dari waktu ke waktu juga ditandai dengan terus berkembangnya budaya manusia yang menapak maju. Berbagai teknologi canggih pun diciptakan untuk kemudahan manusia dalam melakukan berbagai aktivitas. Upaya untuk memenuhi kebutuhan dan aktivitas secara lebih cepat dan mudah terus diupayakan. Setiap saat kita akan menemukan berbagai produk baru yang lebih memudahkan dan memanjakan manusia dalam menjalankan pekerjaan dan aktivitasnya sehari-hari.

Setiap teknologi senantiasa membawa dampak ikutan, baik dampak positif maupun dampak negatif. Dampak positif tentu harus dikembangkan agar dapat membantu menuju kepada kehidupan

2 Syukri Hamzah, Prof.Dr. MSi, Pendidikan Lingkungan (Sekelumit Wawasan Pengantar), Bandung, PT. Refika Aditama, 2013, hal.73 yang lebih kondusif. Namun terhadap dampak negatif tentu saja harus dikurangi dan bila mungkin dapat dicegah untuk tidak terjadi.

Kaidah yang harus tetap dipegang dalam penataan ruang terhadap pembangun an adalah setiap perubahan harus lebih baik dari hari sebelumnya, yakni masa depan yang lebih sejahtera, nyaman tanpa dihantui kecemasan dan ketakutan akan berbagai ancaman fenomena, seperti lingkungan hidup yang tidak sehat karena tidak jelas penataan ruangnya, bencana alam karena pemanfaatan sumber alam secara membabi buta dan tindakan-tindakan lainnya yang tanpa perencanaan, tanpa penataan dan lain-lain.

Di dalam kehidupan sosial, pengaruh lingkungan terhadap perilaku manusia dicirikan pada karakteristik soal tertentu pada suatu masyarakat. Hal ini merupakan hasil proses adaptasi dan interaksi manusia terhadap lingkungan tempatia berdomisili. Perilaku itu merupakan suatu kegiatan yang tidak terjadi secara semena-mena, akan tetapi disebabkan oleh aktivitas yang dilakukan manusia karena adanya rangsangan yang datang dari luar untuk mencapai tujuan tertentu.

Sebagaimana dikemukakan oleh Carry dalam Syukri Hamzah, perilaku lingkungan itu itu dipengaruhi oleh beberapa faktor, seperti norma subjektif, keyakinan berperilaku, dan adanya control yang berasal dari sumber perilaku dan kesempatan. Karena itu keaneka ragaman kondisi lingkungan akan merupakan suatu tantangan sekaligus stimulasi bagi manusia untuk survive yang selanjutnya akan mendorong manusia untuk mengembangkan potensi yang dimiliki agar ia dapat memanfaatkan segala sesuatu yang telah tersedia di lingkungannya secara maksimal. ${ }^{3}$

Berdasarkan uraian Carry di atas, menunjukkan bahwa antara manusia dan lingkungan terjadi suatu proses saling pengaruh dan mempengaruhi yang akhirnya akan membentuk perilaku pada

3 Syukri Hanzah, Prof,Dr, MSi, Ibid, hal. 3 
manusia.

Keberadaan lingkungan yang layak huni bagi manusia merupakan sesuatu kebutuhan yang tak dapat diabaikan. Kehidupan manusia sangat bergantung dan dipengaruhi oleh kondisi dan keberadaan lingkungannya. Lingkungan hidup yang nyama, menyenangka, berkecukupan dan asri merupakan condition sine quanon atau suatu keharusan yang tak terelakkan lagi.

Sumarwoto menyatakan bahwa baku mutu lingkungan yang baik akan membuat orang kerasan hidup dalam lingkung tersebut. Kekerasan tersebut bukanlah karena terpenuhi nya satu atau dua faktor saja, melainkan adanya integrasi faktor-faktor lingkungan secara optimum. Mutu lingkungan dapat diartikan sebagi kondisi lingkungan dalam hubungannya dengan mutu hidup. Makin tinggi derajat mutu hidup dalam suatu lingkungan tertentu, makin tinggi pula derajat mutu lingkungan tersebut. ${ }^{4}$

Permasalahan kependudukan yang ada saat sekarang ini sudah cukup komplek, yakni berkaitan dengan persoalan jumlah, kualitas, komposisi dan persebarannya. Bertambahnya jumlah penduduk dapat berdampak positif dan negatif. Bertambahnya jumlah penduduk berarti bertambahnya potensi tenaga kerja. Di sisi lain, bertambahnya jumlah penduduk berarti pula bertambahnya jumlah kebutuhan yang harus dipenuhi, baik itu sandang, pangan maupun papan di samping masalah tata ruang untuk wilayah hunian. Sedangkan dampak terhadap lingkungan adalah meningkatnya kebutuhan akan sumber daya alam. Kondisi ini sudah pasti akan memberikan tekanan terhadap keberadaan sumber daya alam. Keadaan ini sudah pasti akan memberikan tekanan terhadap keberadaan sumber daya alam. Bilamana tekanan tersebut melewati ambang batas daya dukung yang ada maka kerusakan lingkungan tak mungkin terhindarkan, bahkan boleh jadi akan berujung dengan bencana lingkungan. Karena itu, pertumbuhan penduduk bagaimanapun perlu dikendalikan sehingga daya dukung lingkungan dapat terjaga serta

4 Soemarwoto, Atur Diri Sendiri Paradigma Baru Pengelolaan Lingkungan Hidup, Yogyakarta, Gajahmada University Press, hal. 56. kebutuhan manusia akan sumber daya alam dapat terimbangi. Di samping itu, kita dapat mengurangi potensi kehadiran kerawanan sosial seperti kemiskinan, pengangguran.

Persebaran penduduk yang tidak merata antara lain disebabkan oleh kecenderungan manusia selalu mencari tempat yang strategis dari segi ekonomi .Hal ini pula menjadi pemicu terjadinya ketidak merataan pelaksanaan pembangun an antar daerah sehingga terjadi ketimpangan kemajuan antar daerah yang selanjutnya berpengaruh kepada konsentrasi kegiatan ekonomi.

Pandangan economic strategic menjadi motif utama terjadinya mobilisasi dan urbanisasi penduduk ke suatu daerah, akibatnya terjadi berjubelnya manusia di suatu daerah (misalnya: pulau Jawa) yang membawa konsekwensi makin sempitnya lahan hunian dan garapan yang juga dapat berdampak sulitnya lapangan pekerjaan. Sedangkan daerah yang huniannya jarang menjadi wilayah itu kurang produktif karena terbatasnya tenaga kerja, namun bisa juga terjadi kondisi sebaliknya karena tenaga kerja tersedia tetapi infrastruktur yang tidak mendukung.

Pemandangan lain dapat kita temukan juga yang berkaitan dengan masalah penduduk, khususnya yang berkaitan dengan pemenuhan kebutuhan hidup. Kebutuhan hidup adalah suatu hal yang tidak dapat ditunda pemenuhannya. Oleh karena itu untuk memenuhi kebutuhan hidupnya tersebut penduduk memanfaat kan lahan kebun hingga ke puncak-puncak bukit dan gunung karena makin terbatasnya lahan untuk berkebun. Bukit dan gunung yang semula berupa hutan berubah kini telah banyak yang rusak dan gundul karena dirambah oleh manusia untuk membuat ladang. Banyak hutan yang berstatus hutan lindung telah beralih fungsinya menjadi areal perladangan masyarakat.

Sikap hidup manusia yang cenderung serba ingin mudah dan memanja kan diri sendiri tanpa mempedulikan orang 
lain memberikan dampak kerugian manusia lainnya, seperti pembangunan vila dan rumah mewah di kawasan penyanggah dan wilayah tangkapan air, pembangunan perumahan oleh para pengembang dengan dalih memenuhi kebutuhan rumah untuk masyarakat serta pembangunan gedunggedung bertingkat di kota-kota besar yang telahmenyerupai hutan beton, telah pula menyumbangkan kerusakan lingkungan yang cukup parah. Kenyataan ini seharus nya segera menyadarkan kita bahwa bencana-bencana yang terjadi di alam semesta ini bukan semata-mata karena fenomena alam, melainkan juga dapat merupakan akibat ulah manusia.

Permasalahan lingkungan yang bersumber dari tekanan pertumbuhan penduduk yang cepat serta pengaruhnya terhadap keberadaan ruang dan lahan yang tidak diiringi dengan kepedulian terhadap lingkungan, kalau dibiarkan terus tanpa suatu upaya pengendalian, maka sangat berbahaya karena apabila datang musim hujan akan menjadi penyebab bencana banjir dan tanah longsor yang dapat merusak areal tanaman maupun hunian penduduk.

Semakin beragamnya kebutuhan yang dihadapi manusia telah memacu manusia untuk mencari upaya pemecahan nya. Kebutuhan manusia tidak hanya terbatas pada kebutuhan primer dan sekunder saja, tetapi juga kebutuhan tersier. Keinginan untuk hidup nyaman, sejahtera bahkan adanya keinginan yang serba mudah telah mengantarkan manusia pada upaya-upaya kreatif menciptakan berbagai teknologi guna mempertahankan hidup dan untuk mewujudkan kesejahteraan kehidup an manusia menjadi ketergantungan.

Berkaitan dengan teknologi itu sendiri manusia tidak menyadari bahwa setiap teknologi akan membawa konsekuensi berupa dampak yang menyertainya, baik itu dampak positif ataupun negatif. Dampak negatif dari penggunaan teknologi sering terabaikan oleh manusia, karena pada umunya manusia hanya melihat dampak positif yang diterima dan dirasakan dari suatu produk teknologi berupa kemudahan, kepraktisan dan lain-lain. Dampak negatif dari pemanfaatan teknologi apabila tidak diantisipasi dan dikolola dengan baik dapat menyebabkan bencana bagi kehidupan umat manusia. Manusia yang diciptakan oleh Allah, Tuhan yang maha kuasa harus mampu berbuat berinisiatif untuk mencegah terjadinya hal-hal negatif akibat teknologi yang digunakan pada kehidupan manusia. Keinginan mencegah agar terhindar dari hal-hal negatif sebenarnya merupakan fitrah nya manusia, walaupun dalam banyak hal dan kesempatan banyak terabaikan.

Manusia mampu berfikir dan berbuat bagi terwujudnya suatu kondisi yang baik dan sejahtera, maka manusia harus mampu mencegah bencana lingkungan terhadap kehidupan manusia di muka bumi.

Jangan sampai kemajuan teknologi justru menyebabkan manusia mengalami keterbelakang dan kemiskinan. Banyak para pakar di berbagai bidang menyatakan bahwa kemiskinan dan degradasi lingkungan dapat memiliki hubungan yang signifikan. Ketergantungan manusia terhadap sumber daya alam cukup tinggi, seperti untuk kebutuhan pangan, bahan bakar, tempat tinggal, seringkali mengabaikan dampak ekploitasi yang dilakukan terhadap kondisi lingkungan tempat sumber daya alam itu. Kebutuhan hari ini yang harus dipenuhi telah mengabaikan bencana yang dapat terjadi esok hari.

Keterbelakangan dan kemiskinan masih merupakan fenomena yang kita hadapi dalam kehidupan masyarakat saat ini. Sementara ada banyak pakar di berbagai bidang yang berkaitan dengan hal ini menyatakan bahwa kemiskinan dan degradasi lingkungan dapat memiliki hubungan yang cukup signifikan. 
Ketergantungan masyarakat kita terhadap sumber daya alam cukup tinggi, seperti untuk kebutuhan pangan, bahan bakar, tempat tinggal, dan lainnya. Dalam memanfaatkan sumber daya alam guna memenuhi kebutuhan dasanya tersebut, banyak masyarakat yang mengabaikan dampak eksploitasi yang dilakukannya terhadap kondisi lingkungan tempat sumber daya alam itu ada. Kebutuhan dasar yang mendesak untuk dipenuhi telah menyebabkan mereka melupakan dampak negatif lingkungan yang mungkin timbul akibat perilakunya. Kebutuhan hari ini yang harus dipenuhi telah mengabaikan bencana yang dapat terjadi hari esok. Perilaku yang tak peduli pada kondisi lingkungan ini merupakan tantangan terhadap kemungkin an terjadinya degradasi lingkungan.

Keterbelakangan dan kemiskinan ini merupakan salah satu masalah yang banyak dihadapi oleh Negara-negara berkembang, termasuk Negara kita Indonesia. Keterbelakang an dan kemiskinan mempunyai hubungan yang erat dengan kerusakan lingkungan. Rachmat Witular, Mentari Lingkungan Hidup Republik Indonesia, dalam sambutannya pada acara pembukaan StoS 2008 di Geothe Institute Jakarta 25 Januari 2008, menyatakan bahwa kemiskinan dan lingkungan hidup bagaikan dua sisi mata uang yang sama. Bila masyarakat miskin maka lingkungan pun akan rusak. Menurutnya, kerusakan sumber daya alam akan menjadi pangkal tolak kerusakan sisi kehidupan lainnya. Untuk itu, tanggung jawab kebersihan dan keberlanjutan lingkungan hidup tidak hanya pada otoritas kebijakan saja, tetapi juga pada masyarakat. ${ }^{5}$

Rissalwan Habdy Lubis dalam Syukri Hamzah menyatakan "Kemiskinan dan Lingkungan: ( Kasus Komunitas Lahan Basah di kota Depok dan Jakarta )"menyatakan bahwa sejak tahun 1970-an telah banyak pihak yang menyepakati bahwa kemiskinan dan kemunduran kualitas lingkungan memang memiliki keterkaitan yang sangat kuat. ${ }^{6}$

Orang miskin terpaksa mengambil manfaat dari sumber daya alam secara

\footnotetext{
5 http//ww.jatam.org/

6 Syukri Hanzah, Prof,Dr, MSi, Loc cit, hal. 12
}

berlebihan agar bisa bertahan hidup., dan pengabaian terhadap lingkungan mereka pada akhimya mengabaikan mereka, hingga akhirnya kemampuan mereka untuk bertahan hidup menjadi semakin sulit dan tidak pasti. Hal-hal yang dikemukakan di atas menunjukkan bahwa upaya pengelolaan lingkungan yang dilaksanakan akan kurang efektif apabila sebagian besar masyarakat masih berada di bawah garis kemiskinan. Dalam hal ini masyarakat lebih terkonsentrasi pada kebutuhan primernya dan cenderung bersikap kurang peduli dengan lingkungannya. Berbagai kasus menunjukkan bahwa faktor kemiskinan dan ketidak berdayaan masyarakat untuk memenuhi kebutuhan hidup secara layak telah memberikan dampak terhadap kualitas lingkungan hidup. Kemiskinan akibat krisis ekonomi yang kita alami beberapa waktu yang lalu merupakan contoh nyata. Sampai dengan saal ini ada banyak penjarahan terhadap hutan kawasan konservasi dan hutan lindung yang dilakukan masyarakat semata-mata hanya untuk memenuhi kebutuhan hidup.

Hasil proses pendidikan akan memungkinkan seseorang dapat mengembangkan potensi yang dimilikinya. Dengan bekal pengetahuan yang dimiliki nya memungkinkan pula baginya untuk berkontribusi dan berkiprah dalam pembangunan dan pengembangan masyarakat. Hal ini bermakna bahwa pendidikan merupakan salah satucara yang patut ditempuh untuk memberikan pengetahuan serta membentuk sikap dan kepedulian masyarakat terhadap lingkungan sebagaimana diinginkan. Pendidikan mempunyai arti yang sangat penting dalam diri seseorang yang menyangkut aspek kognitif berupa kemampuan akademik dan kemampuan memecahkan masalah. Lebih lanjut ia menyatakan bahwa pendidikan dalam prosesnya mencakup tujuan pengembangan aspek pribadi dan sosial yang memungkin kan orang bekerja dan hidup dalam suatu 
kelompok secara kreatif, berinisiatif, berempati, serta memiliki keterampilan interpersonal yang memadai sebagai bekal hidup di masyarakat.

Pengelolaan lingkungan yang efektif bergantung pada upaya kita dalam mengadopsi etika lingkungan secara baik dalam perilaku kita. Perilaku yang ditunjukkan adalah perilaku yang mencerminkan sikap ramah lingkun serta kemampuan mempertahankan keaneka ragaman hayati yang dapat mendukung kehidupan. Dengan demikian, pendidikan harus dapat dimanfaatkan sebagai sarana pembentukan sikap dan kepedulian terhadap lingkungan secara elektif. Pendidikan yang kurang memadai, dalam arti kurang memberikan informasi tentang masalah lingkungan hidup akan menyebabkan kurangnya pengetahuan yang dimiliki masyarakat yang kemudian dapat berakibat munculnya sikap kurang peduli masyarakat pada lingkungan hidup. Sebaliknya, melalui pendidikan yang intensit sangat dimungkinkan untuk meningkatkan kualitas sikap dan perilaku yang positif terhadap lingkungan, karena melalui pendidikan dapat diwujudkan kesiapan mental dan kecenderungan untuk berperilaku positif terhadap suatu objek tertentu yang dalam hal ini adalah lingkungan hidup.

Pendidikan terhadap sumber daya manusia yang kita miliki yang berkaitan dengan upaya-upaya pelestarian lingkungan merupakan hal yang penting diberdayakan. Perubahan sikap manusia yang kita harapkan akan sangat bergantung dari promosi yang luas melalui pendidikan, diskusi, dan partisipasi publik. Sudarsono menyatakan "Bangsa yang membiarkan masalah- masalah sosialnya terlantar mustahil dapat menjadi cukup kuat untuk mencapai atau mempertahankan kelangsungan hidupnya", kiranya patut kita renungkan. Informasi tentang lingkungan kepada masyarakat sangat perlu dilakukan

7 Sudarsono, Yuwono, Pembangunan Politik dan Perubahan Politik, PT. Gramedia, Jakarta, 1985, hal 125 untuk pelaksanaan program konservasi. Hal ini tidak hanya berkaitan dengan penyebaran informasi tentang aturanaturan yang ada dan programpemeliharaan lingkungan, tetapi juga berkenaan dengan fakta-fakta sejarahkehidupan yang mengandung informasi tentang bagaimana individu melindungi lingkungan. Tentang bagaimana penduduk lokal yang mempunyai pemahaman dan penghargaan yang lebih tinggi terhadap lingkungannya yang sikap ini telah semakin berkurang pada generasi muda. Penyebaran informasi yang dilakukan secara berkelanjutan diharapkan akan mampu menggugah kerifan lokal dalam sikap masyarakat terhadap lingkungan.

Menurut Keraf, kearifan lokal adalah semua bentuk pengetahuan,keyakinan, pemahaman atau wawasan, serta adat kebiasaan atau etika yang menuntun perilaku manusia dalam kehidupan komunitas ekologis. ${ }^{8}$

Kearifan sebagaimana dimaksud kan, pada umumnya telah dimiliki dan mentradisi pada banyak masyarakat lokal. Kearifan-kearifan tersebut terwujud dalam perilaku masyarakat lokal ketika ber interaksi dengan lingkungan hidupnya yang diwarisi dari para pendahulunya.

Adimihardja menyatakan bahwa kearifan tradisi tercermin dalam system pengetahuan dan teknologi lokal di masyarakat dan di berbagai daerah yang masih mempertimbangkan nilai-nilai adat, seperti bagaimana masyarakat melakukan prinsipprinsip konservasi, manajemen, dan eksploitasi sumber daya alam, ekonomi, dan sosial. ${ }^{9}$

Pengetahuan masyarakat lokal yang terakumulasi sepanjang sejarah hidup mereka mempunyai peran yang sangat besar. Pandangan tentang manusia sebagai bagian dari alam serta sistem kepercayaan mereka yang menekankan penghormatan terhadap lingkungan alam, merupakan nilai

8 Keraf, Sony, Etika Lingkungan, Jakarta, 2002, Penerbit Buku Kompas, hal. 289.

9 Adimiharja, Kusnaka (ed), Petani Merajut Tradisi Era Globalisasi, Pendayagunaan Sistem Pengetahuan Lokal Dalam Pembangunan, Bandung, Humaniora Utama Press, hal. 7 
yang sangat positif untuk pembangunan berkelanjutan. Kita harus menyadari bahwa pada umumnya masyarakat lokal memiliki kearifan dan pengetahuan lokal yang unggul dan adaptif dengan karakteristik sumber daya alam yang dikelolanya. Namun, kemajuan teknologi informasi yang terus merambah sampai ke pelosok desa di samping kebijakan pemerintah yang tidak berpihak kepada masyarakat, menyebabkan makin terkikisnya kearifankearifan local yang ada di masyarakat.

Prinsip 22 Deklarasi Rio de Jeneiro telah menetapkan bahwa "pemerintah harus memahami dan mengakui identitas, budaya, dan kepentingan masyarakat, serta memberikan dukungan sepatutnya yang memungkinkan tumbuhnya partisipasi yang efektif dalam pembangunan berkelanjutan".

Deklarasi ini seyogianya mengingat kan kita akan pentingnya masalah kearifan lokal ini. Ada banyak kearifan-kearifan warisan nenek moyang kita yang telah terlupakan, terutama oleh generasi muda kita saat ini karena kearifan-kearifan tersebut dianggap kuno dan tertinggal zaman, ditambah lagi dengan derasnya arus globalisasi yang secara perlahan terus menggerus kearifan-kearifan lokal (local indigenous) yang ada. Pengelolaan lingkungan yang ada saat Ini tak banyak lagi yang memperhatikan tradisi pemeliharaan lingkungan yang dulu pernah berlaku, padahal tradisi tersebut merupakan upaya efektir yang mengacu pada pengelolaan kelestarian lingkungan dalam kehidupan masyarakat.

Kebutuhan hidup dan kemiskinan yang kurang terperhatikan oleh pihak berwenang, telah menyebabkan masyarakat tak lagi memperhatikan unsur "tabu, pemali" atau "pantangan" (public rule) yang dahulu berlaku di masyarakat dalam pemanfaatan sumber daya alam. Lebih dari itu, pemberian izin eksploitasi sumber daya alam oleh pemerintah pada pihak swasta-terlebih pada era otonomi saat ini, ada banyak yang tak diikuti dengan pengawasan dan keharusan memperhatikan masalah pelestarian budaya masyarakat setempat. Hal ini makin membuat terpuruknya kearifan lokal yang meng andung nilai-nilai pelestarian lingkungan yang akhirnya berdampak pada kualitas lingkungan hidup masyarakat setempat.

Upaya penggalian dan pelestarian budaya-budaya lokal yang bernilai terhadap kelestarian lingkungan telah banyak dilakukan, namun sejauh ini porsi penerapannya masih belum cukup memadai. Desa Cipta gelar di kaki Gunung Halimun, Sukabumi, adalah contoh yang baik untuk upaya pelestarian lingkungan dengan pendekatan kearifan lokal. Melalui kearifan local pemerintahan desa yang dipimpin oleh Abah Anom dapat meningkatkan kualitas hidup warganya dengan tetap mengindahkan kelestarian lingkungan. Masyarakat Badui di Banten yang kukuh dengan adat budayanya, mampu mempertahankan kondisi lingkungannya. Di lingkungan masyarakat Jawa kita mengenal ilmu "niteni" yang membaca tanda-tanda alam untuk mitigasi bencana alam. Masih banyak lagi contohcontoh yang ada di daerah yang dapat diangkat bahwa pemanfaatan dan pelestarian kearifan lokal merupakan salah satu upaya menjaga kondisi keseimbangan lingkungan.

Seharusnya kita dapat bercermin dan memanfaatkan kearifan-kearifan lokal dalam memelihara kelestarian lingkungan, baik yang terpelihara maupun yang pernah hidup dalam masyarakat tersebut. Artinya, kita perlu melakukan pendekatan terhadap masyarakat pendukungnya guna mengembalikan perilaku dan sikapnya terhadap lingkungan hidup. "Kearifan Masa Lalu adalah Kearifan Masa Depan", bunyi kalimat sebuah poster di Kementerian Lingkungan Hidup Jepang kiranya layak pula menjadi semboyan kita dalam merevitalisasi kearifan-kearifan local dalam pemeliharaan lingkungan yang ada di masyarakat kita. ${ }^{10}$

10 Surat kabar harian Kompas, 25 Juni 2007 
Kebijakan pembangunan yang dilaksanakan oleh Pemerintah akan turut mewarnai bentuk kondisi lingkungan. Paradigma pembangunan yang berorientasi pembangunan ekonomi untuk mengejar pertumbuhan ekonomi cenderung mengabaikan kondisi lingkungan, baik lingkungan alam maupun social budaya. Di era otonomi daerah saat ini, telah cukup banyak lingkungan alam yang rusak karena izin penambangan yang dikeluarkan oleh Pemerintah Daerah yang semata- mata bertujuan untuk mengisi dompet PAD. Fasilitas infrastruktur yang rusak dan hancur karenanya, pun menjadi salah satu indikasi kurangnya perhatian dimaksud. Pada beberapa wilayah di Indonesia, cukup banyak hutan yang dirambah hanya untuk kepentingan penanaman modal investor di sector pertambangan. Sementara, sumbang an yang diperoleh untuk PAD jauh lebih sedikit dari pada kerusakan lingkungan yang ditimbulkannya. Berkenaan dengan paradigma pembangunan yang berorientasi pada pembangunan ekonomi ini, Keraf mengungkapkan, "Paradigma dan pola pembangunan seperti ini, terbukti mengabaikan atau memberi perhatian yang sangat minim terhadap lingkungan hidup dan pembangunan sosial-budaya. Akibatnya, kendati membawa kema- juan ekonomi yang menjamin kesejahteraan ekonomi umat manusia di banyak negara, tetapi di banyak negara juga terbukti membawa kerugian yang tidak sedikit dalam bentuk kehancuran dan pencemaran lingkungan hidup serta punahnya berbagai sumber daya alam dan keanekaragaman hayati. Paradigma dan pola pembangunan seperti itu menyisakan berbagai problem kesehatan dan social politik yang kronis, termasuk pelanggar an hak asasi manusia." ${ }^{11}$

Harapan kita, pembangunan yang dilaksanakan hendaknya juga memperhati kan keasrian dan kelestarian lingkungan hidup. Masyarakat yang sejahtera dan sehat merupakan impian kita semua. Karenanya, sudah saatnya perencanaan pembangunan khususnya pada daerah-daerah otonomi

11 Keraf, Sony, Op Cit, hal. 85. juga membangun kapasitas lingkungan sebagai bagian pembangunan yang dilaksanakannya. Kiranya saatnya pemerintah daerah tidak menutup mata terhadap hal-hal yang berkaitan dengan masalah ini. Pembangunan yang dilakukan ditujukan untuk mewujudkan kesejahteraan dan kehidupan yang lebih baik pada manusia, maka setiap kegiatan pembangunan harus memperhitungkan secara komprehensif dampak ikutan yang merupakan bagian konsekuensi bagian pembangunan. Dampak ikutan harus dicermati secara sungguh-sungguh agar pembangunan yang dilakukan dapat sesuai dengan tujuan yang diinginkan. Pembangunan yang hanya mementingkan kegiatan ekonomi semata tanpa mem perhatikan kondisi-kondisi di masyarakat tidak menguntungkan, karena pada hekekatnya masyarakat lah yang menjadi subjek dari pembangunan itu sendiri. Penataan ruang yang semata-mata mempertimbangkan dari segi ekonomis semata atau atas permintaan pasar saja akan menyebabkan tercapainya perkembangan ekonomi di suatu daerah, namun justru menyebabkan merosotnya mutu lingkung an hidup itu sendiri.

Pembangunan mengandung arti perbaikan mutu kehidupan manusia dengan tetap berusaha tidak melampaui kemampuan ekosistem untuk mendukungnya. Pembangun an bukan untuk pembangunan, tetapi pembangunan untuk menujukehidupan yang lebih baiksaat ini dan masa yang akan datang.

Penataan ruang adalah menye imbangkan pembangunan ekonomi, sosial dan lingkungan secara berkesimbungan melalui :

1. Menciptakan peluang pertumbuhan di masa depan dan pekerjaan bagi seluruh warga kota;

2. Menyediakan lingkungan hidup yang berkualitas dilengkapi dengan perumahan yang layak dan berbagai fasilitas untuk memenuhi kebutuhan yang beraneka ragam; 
Pengamanan lingkungan yang lebih bersih dan hijau untuk generasi mendatang. ${ }^{12}$

\section{Kaidah Zonasi Yang Tegas Dan Panjang Umur}

Kaidah kedua dalam penataan ruang adalah dilakukannya pengwilayahan secara tegas dalam jangka panjang umur tanpa perubahan, karena banyak penataan ruang yang begitu mudah berubah dan hanya menuruti keinginan pasar atau pemilik modal. Sekarang banyak kita lihat lahan pertanian produktif, lahan perkebunan produktif, hutan dibabat habis untuk memenuhi permintaan pasaryakni berubah menjadi bangunan industri, perumahan, dan bahkan Ruang Terbuka Hijau (RTH) dan taman kota beralih menjadi Mall.

Undang-Undang No. 26 Tahun 2007 tentang Penataan Ruang mengamanat kan bahwa penyusunan tata ruang nasional, provinsi, kabupaten dan kota harus mendasarkan pada daya dukung lingkungan dan daya tampung lingkungan. Daya dukung lingkungan adalah kemampuan lingkungan hidup untuk mendukung perilaku kehidupan manusia dan makhluk hidup lain dan keseimbangan diantara keduanya. Sedangkan daya tampung lingkungan adalah kemampuan lingkungan hidup untuk menyerap zat, energy dan / komponen lain yang masuk atau dimasukkan kedalamnya.

Pengelolaan lingkungan hidup merupakan suatu kegiatan yang di dalamnya mencakup aspek pemanfaatan, pengaturan dan penataan, pemeliharaan, pemulihan, pengendalian, pembinaan serta upaya pelestarian lingkungan hidup yang dilaksanakan secara integrative.

Kebijaksanaan pembangunan yang dilaksanakan oleh pemerintah akan turut mewarnai bentuk kondisi lingkungan. Paradigma pembangunan yang breorientas

12 Ernady Syadih, Dr. Ir, MT, IAP, Manajemen Pembangunan Kabupaten Kota, Bandung, Aditama, 2015, hal. 2018 kepada pembangunan ekonomi cenderung mengabaikan kondisi lingkungan, baik lingkungan alam ataupun lingkungan budaya. Di jaman sekarang cukup banyak lingkungan hidup yang rusak karena dikeluarkannya ijin penambangan, ijin penebangan hutan oleh pemerintah daerah semata-mata untuk mengejar dompet PAD.

Pola pembangunan seperti tersebut di atas jelas memberi perhatian yang sangat minim terhadap lingkungan hidup dan pembangunan social budaya. Walaupun memberi kemajuan ekonomi dan sepertinya membawa kesejahteraan umat manusia tetapi tidak sedikit justru membawa bencana alam dan pencemaran lingkungan hidup serta punahnya berbagai sumber daya alam dan keaneka ragaman hayati.

Pembangunan harus tetap dilaksana kan untuk mengatasi masalah-masalah lingkungan sebagai akibat keterbelakangan pembangunan dan kemiskinan penduduk, tetapi tidak merusak atau mencemari lingkungan, yang selanjutnya dikenal dengan pembangunan berwawasan lingkungan (eco-development). ${ }^{13}$

Pengaturan zonasi merupakan ketentuan yang mengatur tentang persyaratan pemanfaatan ruang dan ketentuan pengendaliannya dan disusun untuk setiap blok atau zona peruntukan yang penetapan zonanya dalam rencana rinci tata ruang. Rencana rinci tata ruang daerah kabupaten/kota dan peraturan zonasi yang melengkapi rencana rinci tersebut harus tegas dan tetap dipertahan kan selama mungkin.

Azas Dalam kerangka Negara Kesatuan Republik Indonesia, penataan ruang diselenggarakan berdasarkan asas: Keterpaduan, maksudnya penataan ruang diselenggarakan dengan meng itegrasikan berbagai kepentingan yang bersifat lintas sektor, lintas wilayah, dan lintas pemangku kepentingan.keserasian, keselarasan, dan

13 Muhammad Akib, Dr, SH.MHum. Hukum Lingkungan Perspektif Global dan Nasional, Jakarta, PT. Raja Grafindo Persada, 2013, hal. 8 
keseimbangan, maksud nya penataan ruang diselenggarakan dengan mewujudkan keserasian antara struktur ruang dan pola ruang, keselarasan antara kehidupan manusia dan lingkungan nya, keseimbang an pertumbuhan dan perkembangan antar daerah dan kawasan perkotaan dan kawasan perdesaan.

Keberlanjutan, maksudnya penata an ruang diselenggarakan dengan menjamin kelestarian dan kelangsungan daya dukung (kemampuan lingkungan hidup untuk mendukung kehidupan yang berlangsung padanya secara wajar, yang berimplikasi dengan kerusakan lingkungan hidup) dan daya tampung (menyangkut kemampuan lingkungan hidup untuk menyerap zat dan benda lainnya yang masuk pada badan lingkungan hidup tersebut, dan berimplikasi dengan pencemaran lingkungan hidup) lingkungan hidup dengan memerhatikan kepentingan generasi mendatang.

Keberdayagunaan dan keberhasil gunaan, maksudnya penataan ruang diselenggrakan dengan mengoptimalkan manfaat ruang dan sumber daya (SDA) yang terkandung di dalamnya serta menjamin terwujudnya tata ruang yang berkulitas.

Keterbukaan, maksudnya penataan ruang diselenggarakan dengan memberikan akses yang seluas-luasnya kepada masyarakat untuk mendapatkan informasi yang berkaitan dengan penataan ruang. kebersamaan dan kemitraan, maksudnya penataan ruang diselenggarakan dengan melibatkan seluruh pemangku kepenting an. Perlindungan kepentingan umum, maksudnya penataan ruang diseleng garakan dengan mengutamakan kepenting an masyarakat. kepastian hukum dan keadilan, maksudnya penataan runag diselenggarakan dengan berlandaskan hukum atau ketentuan peraturan perundang-rundangan dan bahwa penataan ruang dilaksanakan dengan memper timbangkan rasa keadilan masyarakat serta melindungi hak dan kewajiban semua pihak secara adil dengan jaminan kepastian hukum. Akuntabilitas, maksudny penataan ruang dapat dipertanggungkan jawabkan, baik prossnya, pembiayaannya, maupun hasilnya.

Penyelenggaraan penataan ruang bertujuan untuk mewujudkan ruang wilayah nasional yang aman, nyaman, produktif, dan berkelanjutan berlandaskan Wawasan Nusantara dan Ketahanan Nasional, yaitu: Mewujudkan wilayah nasional yang aman, maksudnya situasi masyarakat dapat menjalankan aktivitas kehidupannya dengan terlindungi dari berbagai ancaman. Mewujudkan wilayah nasional yang nyaman, yakni suatu keadaan masyarakat dapat mengartikulasikan (berperan mewujudkan atau mengaktuali sasikan sesuatu dalam kehidupannya secara nyata) nilai sosial budaya dan fungsinya dalam suasana yang tenang dan damai. Mewujudkan wilayah nasional yang produktif, maksudnya proses produksi dan distribusi berjalan secara efisien sehingga mampu memberikan nilai tambah ekonomi untuk kesejahteraan masyarakat, sekaligus meningkatkan daya saing. Mewujudkan wilayah nasional yang berkelanjutan, maksudnya kondisi kualitas lingkungan fisik dapat dipertahankan bahkan dapat ditingkatkan, termasuk pula antisipasi untuk mengembangkan orientasi ekonomi kawasan setelah habisnya SDA tak terbarukan.

Menurut Undang-undang Republik Indonesia Nomer. 26 TAHUN 2007 Tentang Penataan Ruang, penataan ruang diklasifikasikan berdasarkan sistem, fungsi utama kawasan, wilayah administratif, kegiatan kawasan, dan nilai strategis kawasan, yaitu : Penataan ruang diselenggarakan dengan memperhatikan: kondisi fisik wilayah Negara Kesatuan Republik Indonesia yang rentan terhadap bencana;potensi sumber daya alam, sumber daya manusia, dansumber daya buatan; kondisi ekonomi, sosial, budaya, politik, 
hukum, pertahanan keamanan, lingkungan hidup, serta ilmu pengetahuan dan teknologi sebagai satu kesatuan; dan geostrategi, geopolitik, dan geoekonomi. Penataan ruang wilayah nasional, penataan ruang wilayah provinsi, dan penataan ruang wilayah kabupaten/kota dilakukan secara berjenjang dan komplementer. Penataan ruang wilayah nasional meliputi ruang wilayah yurisdiksi dan wilayah kedaulatan nasional yang mencakup ruang darat, ruang laut, dan ruang udara, termasuk ruang di dalam bumi sebagai satu kesatuan. Penataan ruang wilayah provinsi dan kabupaten/kota meliputi ruang darat, ruang laut, dan ruang udara, termasuk ruang di dalam bumi sesuai dengan ketentuan peraturan perundang-undangan.

Perencanaan pembangunan daerah merupakan satu kesatuan dalam sistem perencanaan pembangunan nasional. Perencanaan pembangunan daerah dilaku kan pemerintah daerah bersama para pemangku kepentingan berdasarkan peran dan kewenangan masing-masing. Perencanaan pembangunan daerah meng integrasikan rencana tata ruang dengan rencana pembangunan daerah. Perencana an pembangunan daerah dilaksanakan berdasarkan kondisi dan potensi yang dimiliki masing-masing daerah, sesuai dinamika perkembangan daerah dan nasional.

Untuk kriteria tertentu misalnya, wilayah modal, batas bisa berubah dari satu kurun waktu ke kurun waktu berikutnya sesuai dengan perubahan potensi pusatnya. Menurut Hanafiah (1982), unsur-unsur ruang yang terpenting adalah

1. Jarak

2. Lokasi

3. Bentuk, dan

4. Ukuran atau skala

Artinya, setiap wilayah harus memiliki keempat unsur di atas. Unsurunsur di atas secara bersama-sama membentuk/menyusun suatu unit ruang yang disebut wilayah yang dapat dibedakan dari wilayah lain. Dapat dibedakan berdasarkan kondisinya atau berdasarkan fungsinya. Berdasarkan kondisinya, wilayah dapat dikelompokkan atas keseragaman isinya (homogeneity) misalnya wilayah perkebunan, wilayah peternakan, wilayah industri, dan lain-lain. Berdasarkan fungsinya, wilayah dapat dibedakan misalnya kota dengan wilayah belakangnya, lokasi produksi dengan wilayah pemasarannya, susunan orde perkotaan, hierarki jalur transportasi, dan lain-lain. Pengertian wilayah yang diguna kan dalam perencanaan dapat berarti suatu wilayah yang sangat sempit atau sangat luas, sepanjang di dalamnya terdapatunsur ruang atau space. Untuk kepentingan perencanaan maka wilayah harus dapat dibagi (partitioning) atau dikelompokkan (grouping) ke dalam satu kesatuan agar bisa dibedakan dengan kesatuan lain. Apakah kita membagi atau mengelompokkan tergantung pada titik awal ruang wilayah yang kita maksudkan. Apabila titik awal adalah ruang yang luas dan ingin dianalisis dalam bentuk sub bagiannya maka yang kita lakukan adalah membagi wilayah yang luas kedalam beberapa sub wilayah di mana pembagiannya sesuai dengan kriteria yang ditetapkan. Demikian pula apabila titik awalnya adalah wilayah yang kecil-kecil dan ingin dikelompokkan dalam beberapa kesatuan yang lebih besar, hal ini dilakukan mengikuti kriteria yang digunakan. Satuan yang baru itu tetap jugadinamakan wilayah tetapi dengan tambahan ciri/karakter tertentu sehingga dapat kita bayangkan luasnya lebih kecil atau lebih besar dari luas titik awalnya. Misalnya,wilayah negara Republik Indonesia dapat dibagi atas provinsi, provinsi dapat dibagiatas kabupaten/kota, kabupaten/kota dapat dibagi atas kecamatan, kecamatan dibagi atas desa/kelurahan, dan desa/kelurahan dibagi atas dusun lingkungan. Di sisi lain kita bisa beranjak dari wilayah yang kecilkecil, misalnya beberapa desa/kelurahan digabung menjadi satu kecamatan, 
beberapa kecamatan digabung menjadi kabupaten/kota, dan seterusnya. Pembagi an di atas menggunakan kriteria yurisdiksi administrasi pemerintahan, tentunya bisa dibuat pembagian/pengelompokan lain dengan menggunakan kriteria berbeda.

Kata region (wilayah) saat ini bahkan digunakan untuk mencakup wilayah beberapa negara sekaligus. Menjadikan wilayah beberapa negara sebagai satu kesatuan haruslah ada dasarnya, misalnya karena ada ikatan seperti kerja samaekonomi, pertahanan, dan lain-lain. Dengan demikian, patut dipertanyakan apakondisi umum yang harus dipenuhi agar sekelompok wilayah negara itu dapat dijadikan satu kesatuan ruang. Sebetulnya faktor yang dapat mengelompokkan wilayah itu tergantung pada tujuan pengelompokan itu sendiri. Dalam kerangka analisis ekonomi/sosial maka wilayah yang dikelompokkan dalam satu region bagian- bagian nya haruslah berhubungan erat antara yang satu dengan yang lainnya. Dengan demikian, perubahan di salah satu baguan/unit daerah akan berpengaruh pada bagian unit lainnya. Apabilah region itu adalah kumpulan Wilayah beberapa negara maka di dalam negara harus terjadi perpindahan faktorfaktor produksi ( tenaga kerja, modal dan teknologi ) secara mudah dibandingkan dengan perpindahan ke negara lain. Perpindahan itu sendiri terjadi dalam frekuensiyang relatif tinggi. Oleh sebab itu, suatu region selalu terdiri dari sekelompok daerah/negara yang letaknya berdekatan satu sama lain atau bertetangga karena faktor jarak sangat mempengaruhi kelancaran dan frekuensi hubungan. Sudah tentu letak yang berdekatan saja tidak cukup untuk mengelompokannya dalam satu region, tetapi harus di sertai dengan hubungan yang erat / ikatan. Daerah / negara yang berdekatan tetapi terisolasi atau saling menutup pintu antara satu dengan yang lain sulit diangkap sebagai satu region ( dari sudut pandang ekonomi atau sosial ) kecuali jika tujuan penetapan region itu sendiri ialah agar isolasi itu terbuka dan dikemudian hari akan terjadi hubungan yang erat antara unit-unit daerah tersebut. Kerjasama pertahanan mungkin memiliki sisi yang berbeda. Wilayah tidak perlu harus berdekatan/bertetangga namun adanya keinginan untuk berhubungan secara erat tetap merupakan persyaratan untuk berhasilnya kerja sama tersebut.

Ada beberapa cara untuk menetapkan suatu perwilayahan. Perwilayahan apabila dilihat dari atas adalah membagi suatu wilayah yang luas, misalnya wilayah suatu negara ke dalam beberapa wilayah yang lebih kecil. Perwilayahan mengelompokkan beberapa wilayah kecil dalam satu kesatuan. Suatu perwilayahan dapat diklasifikasikan berdasarkan tujuan pembentukan wilayah itu sendiri dapat dibedakan sebagai berikut.

1. Berdasarkan wilayah administrasi pemerintahan, di Indonesia dikenal wilayah kekuasaan pemerintahan, seperti provinsi, kabupaten/kota, kecamatan, desa/kelurahan dan dusun/lingkungan.

2. Berdasarkan kesamaan kondisi (homogeneity), yang paling umum adalahkesamaan kondisi fisik. Berdasarkan kesamaan kondisi fisik, Sumatra Utarapemah dibagi atas pantai timur, pegunungan, dan pantai barat. Ada jugaklasifikasi desa berupa desa pantai, desa pedalaman, dan desa pegunungan.Bisa juga pembagian berupa wilayah pertanian dengan wilayah industri, wilayah perkotaan dengan daerah pedalaman. Cara pembagian lainnya, juga berdasarkan kesamaan sosial budaya. Misalnya, daerah-daerah dibagi menurut suku mayoritas, agama, adat istiadat, tingkat pendidikan, tingkat pendapatan, mayoritas masyarakat yang mendiami wilayah tersebut.

3. Berdasarkan ruang lingkup pengaruh ekonomi. Perlu ditetapkan terlebih 
dahulu beberapa pusat pertumbuhan (growth pole atau growth centre) yang kira-kira sama besarnya/rankingnya, kemudian ditetapkan batas-batas pengaruh dari setiap pusat pertumbuh an. Perlu diingat bahwa batas pengaruh antara satu kota dengan kota lainnyahanya dapat dilakukan untuk kota-kota yang sama rankingnya. Karena untuk kota-kota yang berlainan rankingnya, kota yang lebih kecil itu sendiri berada di bawah pengaruh kota yang lebih besar. Misalnya, sulit menetapkan batas pengaruh antara Semarang dengan Demak karena banyak penduduk yang di Demak itu sendiri bepergian secara rutin ke kota Semarang. Jadi, yang dapat dicari batas pengaruh tersebut adalah antara kota yang memiliki ranking yang sama, dimana jumlah penduduk kedua kota tersebut tidak terlalu jauh berbeda.

4. Berdasarkan wilayah perencanaan/ program. Dalam hal ini ditetapkan batas-batas wilayah ataupun daerahdaerah yang terkena suatu program atau proyek di mana wilayah tersebut termasuk ke dalam suatu perencanaan produksinya, bekerja, bersekolah, berobat, rekreasi, dan lain-lain. Perwilayahan seperti ini biasanya dibutuhkan apabila menggunakan untuk tujuan khusus. Misalnya, perencanaan pelestarian daerah aliran sungai (DAS) dimulai dari sumber mata air di pegunungan melintasi wilayah dataran, memasuki daerah pantai dan bermuara ke laut lepas. Aliran itu sendiri bisamelalui wilayah per kebunan, wilayah pertanian darat, wilayah persawahan, permukiman, perkotaan, dan lain-lain sebelum memasuki muara di laut lepas. Aliran sungai itu bisa melewati lebih dari satu provinsi, beberapa kabupaten dan kota, serta berbagai kawasan. Wilayah perencanaan DAS itumenyangkut tangkapan air di pegunungan sebagai sumber mata airnya dan wilayah di kanan kiri sungai mulai dari hulu hingga ke muaranya.

\section{KESIMPULAN}

Kaidah Pembangunan harus lebih baik dari sebelumnya. Kaidah ini adalah masa depan yang lebih sejahtera, nyaman tanpa dihantui kecemasan dan ketakutan akan berbagai ancaman fenomena, seperti lingkungan hidup yang tidak sehat karena tidak jelas penataan ruang nya, bencana alam karena pemanfaatan sumber alam secara membabi buta dan tindakantindakan lainnya yang tanpa perencanaan, tanpa penataan dan lain-lain. Pembangunan sebagai upaya perubahan suatu keadaan untuk menuju kepada suatu keadaan yang dianggap lebih baik dari keadaan sebelumnya. Upaya paling utama yang harus dilakukan adalah dimulai dalam diri setiap individu itu sendiri, baru kemudian meluas kepada lingkungan, karena setiap individu adalah penggerak dalam pelaksanaan pembangunan. Keinginan manusia untuk hidup lebih baik dari waktu ke waktu juga ditandai dengan terus berkembangnya budaya manusia yang menapak maju. Berbagai teknologi canggih pun diciptakan untuk kemudahan manusia dalam melakukan berbagai aktivitas. Upaya untuk memenuhi kebutuhan dan aktivitas secara lebih cepat dan mudah terus diupayakan. Setiap saat kita akan menemukan berbagai produk baru yang lebih memudahkan dan memanjakan manusia dalam menjalankan pekerjaan dan aktivitasnya sehari-hari. Setiap teknologi senantiasa membawa dampak ikutan, baik dampak positif maupun dampak negatif. Dampak positif tentu harus dikembangkan agar dapat membantu menuju kepada kehidupan yang lebih kondusif. Namun terhadap dampak negatif tentu saja harus dikurangi dan bila mungkin dapat dicegah untuk tidak terjadi. 
Kaidah Zonasi yang tegas dan panjang umur. Kaidah ini dilakukannya pengwilayahan secara tegas dalam jangka panjang atau syukur selamanya tanpa perubahan, karena banyak penataan ruang yang begitu mudah beruba dan hanya menuruti keinginan pasar atau pemilik modal. Sekarang banyak kita lihat lahan pertanian produktif, lahan perkebunan produktif, hutan dibabat habis untuk memenuhi permintaan pasaryakni berubah menjadi bangunan industri, perumahan, dan bahkan ruang terbuka hijau (RTH) dan taman kota beralih menjadi Mall. Kebijaksanaan pembangunan yang dilaksanakan oleh pemerintah akan turut mewarnai bentuk kondisi lingkungan. Paradigma pembangunan yang breorientas kepada pembangunan ekonomi cenderung mengabaikan kondisi lingkungan, baik lingkungan alam ataupun lingkungan budaya. Di jaman sekarang cukup banyak lingkungan hidup yang rusak karena dikeluarkannya ijin penambangan, ijin penebangan hutan oleh pemerintah daerah semata- mata untuk mengejar dompet PAD. Keberdayagunaan dan keberhasilgunaan, maksudnya penataan ruang diselenggrakan dengan mengoptimalkan manfaat ruang dan sumber daya (SDA) yang terkandung di dalamnya serta menjamin terwujudnya tata ruang yang berkulitas dalam jangka panjang.

\section{DAFTAR PUSTAKA}

Munadjat Danusaputro, Hukum Lingkungan, Buku I Umum, Jakarta, Bina Cipta, 2005.

Syukri Hamzah, Prof.Dr. MSi, Pendidikan Lingkungan (Sekelumit Wawasan Pengantar), Bandung, PT. Refika Aditama, 2013Soemarwoto, Atur Diri Sendiri Paradigma Baru Pengelolaan Lingkungan Hidup, Yogyakarta, Gajahmada University Press, 2005.

Sudarsono, Yuwono, Pembangunan Politik dan Perubahan Politik, PT. Gramedia, Jakarta, 1985.

Keraf, Sony, Etika Lingkungan, Jakarta, Penerbit Buku Kompas, 2002

Ernady Syadih, Dr. Ir, MT, IAP, Manajemen Pembangunan Kabupaten Kota, Bandung, Aditama, 2015.

Muhammad Akib, Dr, SH.MHum. Hukum Lingkungan Perspektif Global dan Nasional Jakarta, PT. Raja Grafindo Persada, 2013.

Soerjono Soekanto, Kriminologi: Suatu Pengantar, Jakarta: Ghalia Indonesia, 1981.

Salman Luthan, Ad Criteria of Criminalization, Jurnal Hukum No. 1 Vol. 16 Januari 2009: 1 - 17, Yogyakarta: Fakultas Hukum Universitas Islam Indonesia, 2009.

William BlackStone, Commentaries on the Laws of England, United State: University of Chicago Press, 1979.

Y. Sri Susilo, Peranan Hukum dalam Pembangunan Ekonomi, Yogyakarta: Universitas Atma Jaya Yogyakarta, 2002. 